\title{
FUNDACJE ARCHITEKTONICZNE RODZINY ROZDRAŻEWSKICH - PROBLEMY STYLU I ZNACZENIA FORMY
}

Analizując architekturę Rzeczpospolitej Obojga Narodów, powstającą na przełomie wieków XVI i XVII, łatwo dojść do wniosku, że pod względem używanych form był to najbardziej różnorodny okres w dziejach rodzimego budownictwa ${ }^{1}$. W tym czasie ścierają się rozmaite "nurty stylowe”: gotyk, renesans, manieryzm oraz wczesny barok. Tak różnorodny zestaw stosowanych motywów skutkował dziełami trudnymi do jednoznacznej klasyfikacji, czerpiącymi z tradycji średniowiecznej, ale i niestroniącymi od form najnowszych.

Publikacje poświęcone architekturze tego czasu, zwanej najczęściej postgotycką, powstały w niemieckiej nauce już w początkach XX wieku². W tym czasie w Polsce pojawiały się dopiero skromne uwagi nad długim trwaniem tradycji gotyckiej $j^{3}$. Na prace ściśle naukowe trzeba było czekać aż do lat 50. tego stulecia ${ }^{4}$, natomiast pierwsze monograficzne ujęcia problemu w polskiej literaturze opublikowano dopiero w ostatnim dziesięcioleciu ${ }^{5}$. W związku z tym postgotyk należy do zjawisk tylko częściowo przebadanych. Fakt ten przekłada się na powstawanie błędnych tez w próbach syntetycznego

1 A. Grzybkowski, Gotycka architektura murowana w Polsce, Warszawa 2014, s. 271.

2 Omówienie literatury zob. J. Samek, Nawrót do gotyku w sztuce Krakowa 1 poł. XVII wieku, „Foliae Historiae Atrium” 1968, 5, s. 71-72.

${ }^{3}$ Por. M. Sokołowski, G. Worobjew, J.S. Zubrzycki, Kościoły i cmentarze warowne W Polsce, „Sprawozdanie Komisji Historii Sztuki” 1905, 7, szp. 524.

${ }^{4}$ Literaturę omawia P. Gryglewski, De sacra antiquitate. Odwołania do przeszłości w polskiej architekturze sakralnej XVI wieku, Warszawa 2012, s. 260.

${ }^{5}$ Mam tu na myśli wspomniane wyżej dzieło Piotra Gryglewskiego (por. przyp. 4), książkę Grażyny Jurkowlaniec Epoka nowożytna wobec średniowiecza. Pamiątki przeszłości, cudowne wizerunki, dzieła sztuki (Wrocław 2008) oraz niedawno opublikowaną książkę Tomasza Zauchy Tradycja gotycka w architekturze sakralnej ziem ruskich Korony (Kraków 2015). 
ogarnięcia problemu. Przykładowo Andrzej Grzybkowski w ostatnio wydanej książce we wstępie do opisu postgotyku podaje, że w XVI wieku „nie postawiono niemal żadnej budowli gotyckiej czy gotycyzującej od fundamentów, lecz tylko wprowadzano poszczególne elementy - szczyty, sklepienia, łuk ostry"6. Słowa te nie odzwierciedlają prawdziwego stanu rzeczy. W samej Wielkopolsce w XVI wieku budowli "gotycyzujących” postawiono co najmniej kilkadziesiąt, o czym mogłem się przekonać w trakcie prowadzonych w ostatnim czasie badań terenowych.

\section{FUNDACJE ARCHITEKTONICZNE RODZINY ROZDRAŻEWSKICH}

Doskonałym polem badawczym dla rozważań nad ówczesną architekturą są fundacje sakralne Doliwitów Rozdrażewskich ${ }^{7}$. Rodzina ta, zasiedziała w Wielkopolsce od pokoleń, do najwyższych godności doszła w XVI i pierwszej połowie XVII wieku. W drugiej połowie XVI stulecia panował w niej religijny rozbrat, antagonizujący ważnych aktorów polskiej sceny politycznej - protestanta Jana i biskupa włocławskiego Hieronima. Oprócz nich swoje świątynie fundowali także przedstawiciele starszego pokolenia i dalszych linii Rozdrażewskich, a w ich liczbie matka innowiercy Jana - Anna z Łukowa oraz Jan - dalszy kuzyn z linii nowomiejskiej, związany poprzez urzędy kościelne z biskupem Hieronimem. Kościoły tego ostatniego oraz Anny z Łukowa wykańczał jej prawnuk Jakub Rozdrażewski. Mamy tu zatem unitas in pluralitate; pod jednym nazwiskiem skupiają się fundatorzy czterech różnych pokoleń, a wśród nich katolicy i innowierca, świeccy i duchowni oraz mężczyźni i kobieta.

Serię fundacji sakralnych rodziny zapoczątkował protestant Jan Rozdrażewski, podkomorzy, a później kasztelan poznański . W ostatniej ćwierci XVI wieku ${ }^{9}$ wzniósł on w Krotoszynie dla braci czeskich potężny kościół, rozmia-

${ }^{6}$ Grzybkowski, Gotycka architektura murowana..., s. 271.

7 Intensywną działalność fundacyjną Rozdrażewskich dawno już zauważono w literaturze, choć uwaga na ten temat ma charakter wzmianki; wspomina o niej Teresa Jakimowicz, podając jednak przy tym mylną informację nt. wzniesienia przez Rozdrażewskich świątyń w Benicach i Rozdrażewie dla braci czeskich (por. eadem, Sztuka renesansu i manieryzmu. Architektura, w: Dzieje Wielkopolski, t. 1, red. J. Topolski, Poznań 1969, s. 630).

${ }^{8} \mathrm{Na}$ temat Jana Rozdrażewskiego zob. J. Dworzaczkowa i H. Kowalska, [hasło:] Rozdrażewski (Rozrażewski) Jan h. Doliwa, w: Polski Słownik Biograficzny (dalej: PSB), 19891991, 31, s. 371-373, tam dalsza literatura.

9 Datowanie fary krotoszyńskiej nie jest pewne; w literaturze od początku XX wieku przyjmowano, że powstała ona w latach 1592-1597 (tak m.in. K. Krotoski, Dzieje miasta Krotoszyna. Część pierwsza: Miasto Krotoszyn i jego dziedzice za czasów polskich (od 1415 
rami niewiele ustępujący największym gotyckim świątyniom możnowładczym regionu: farze szamotulskiej czy słupeckiej ${ }^{10}$. Była to pierwsza w nowożytnej Wielkopolsce fundacja sakralna o skali porównywalnej z największymi kościołami poprzedniej epoki.

\section{FUNDACJA JANA ROZDRAŻEWSKIEGO}

Fara krotoszyńska (il. 1) jest świątynią z trójnawowym, bazylikowym korpusem poprzedzonym strzelistą wieżą. Wysoka i wąska nawa główna korpusu przechodzi wprost $\mathrm{w}$ niewydzielony chór z wysokimi oknami, zakończonymi łukami pełnymi. Nawy boczne, a także sąsiadujące z nimi od wschodu wyniosłe kaplice, sprawiające wrażenie transeptu, zostały doświetlone oknami ostrołukowymi ${ }^{11}$. Wszystkie siedemnastowieczne człony kościoła opinają przypory. Dopiero przy wnikliwszym spojrzeniu można dostrzec detale niezwyczajne dla architektury średniowiecznej, jak np. płytkie uskoki, pojawiające się naprzemiennie na ścianach bocznych i czołowych przypór.

do 1779), Krotoszyn 1930, s. 52; S. Kozierowski, Szematyzm historyczny ustrojów parafialnych dzisiejszej Archidiecezji Poznańskiej, Poznań 1935, s. 179|. Źródła potwierdzają tylko pierwszą datę, lakonicznie odnosząc ją do czasu „wystawienia kościoła”, por. Archiwum Archidiecezjalne w Poznaniu (dalej: AAP), Acta Visitationum 1790, 53. Cezurą dla ukończenia przynajmniej większej części prac jest pochowanie w świątyni w roku 1600 fundatora i jej katolicka konsekracja w roku 1601. Natomiast zarówno forma, jak i gotycka technika murowania kościoła nie stoją na przeszkodzie, by jego budowę przesunąć przed rok 1592 - momentem granicznym jest tu jedynie czas przejęcia dóbr krotoszyńskich przez Rozdrażewskich, tj. rok 1570 (na ten temat oraz na temat pochówku Jana Rozdrażewskiego i konsekracji kościoła zob. Krotoski, Dzieje miasta Krotoszyna, s. 43, 55-59|.

${ }_{10}$ Nie zachowały się co prawda dokumenty świadczące wprost o wzniesieniu kościoła dla braci czeskich, jednak istnieją co do tego istotne przesłanki. Przede wszystkim Jan Rozdrażewski należał do Jednoty, po wtóre w roku 1574 nadał zborowi braci czeskich w Krotoszynie „całe dotychczasowe uposażenie katolickiego plebana” (ibidem, s. 372). Znamy też z imienia i nazwiska ówczesnego predykanta krotoszyńskiego, Pawła Orlika, oraz jego następcy, Jana Turnowskiego (ibidem, s. 51). Protestanci trzymali w tym czasie kościoły farny i szpitalny pw. śś. Fabiana i Sebastiana, natomiast katolikom został „pradawny kościółek św. Marii Magdaleny na Starym Krotoszynie" (ibidem, s. 48). Po śmierci fundatora obecna fara została przekazana katolikom i od tego czasu funkcjonuje jako kościół parafialny.

${ }^{11}$ Kaplicom tym od wschodu towarzyszą późniejsze, osiemnastowieczne aneksy zakrystii i kaplicy. 


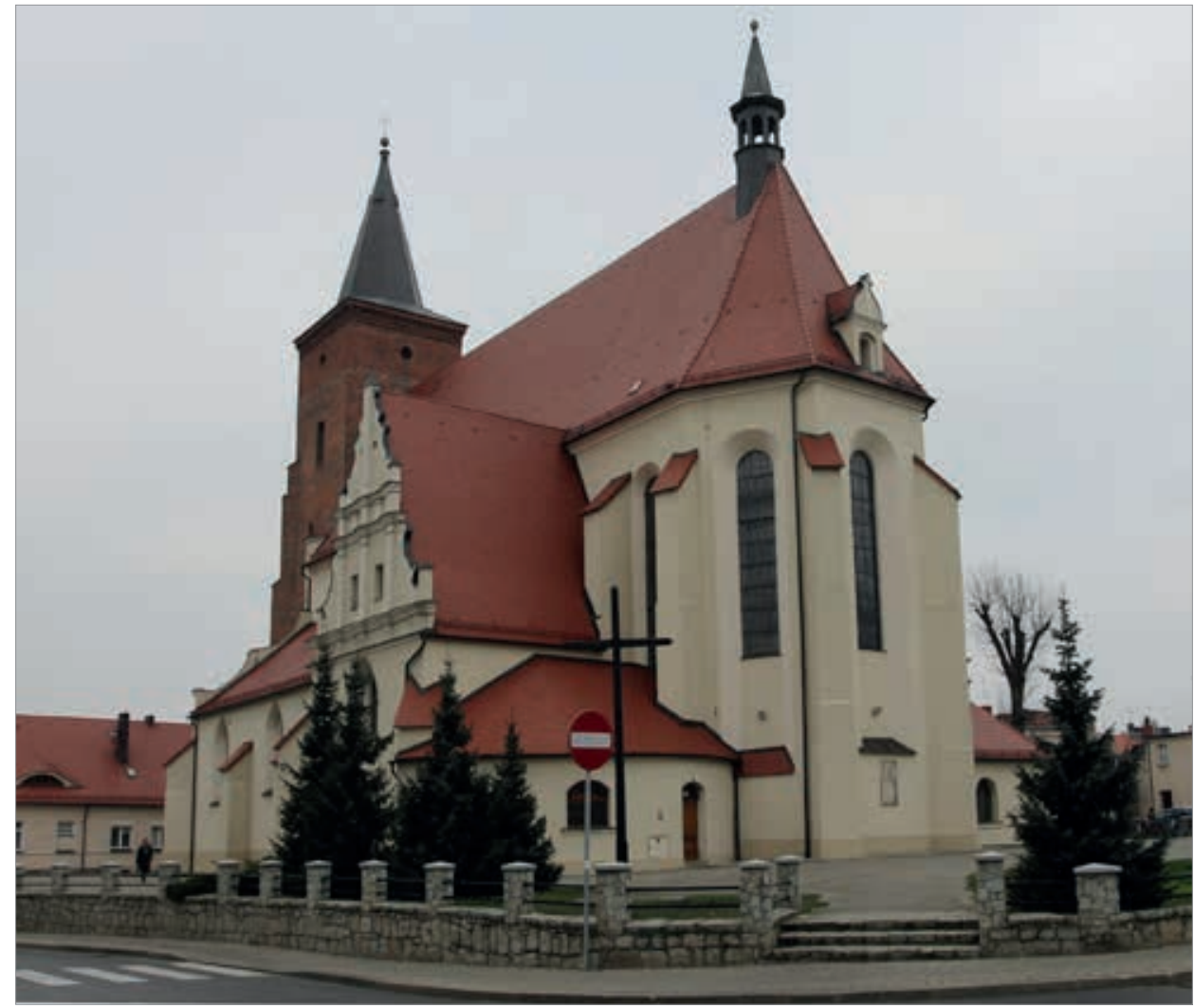

1. Kościół parafialny w Krotoszynie, widok od południowego wschodu, ostatnia ćwierć XVI w., fot. W. Miedziak

O charakterze wnętrza decyduje połączenie gotyckiego typu bazyliki filarowej z oszczędnie stosowaną, renesansową dekoracją (il. 2). Nawa główna została skomunikowana $z$ nawami bocznymi za pomocą arkad zamkniętych łukiem pełnym. Nawy boczne oraz kaplice nakryto sklepieniami krzyżowymi wspartymi na konsolach w formie kolejno lwich masek oraz uskrzydlonych główek. Nawę główną i chór nakrywa sklepienie kolebkowe z lunetami, których krawędzie dekorują stiukowe listwy ${ }^{12}$.

${ }^{12}$ Nie ma jednak pewności, czy sklepienie pochodzi z czasów budowy kościoła, czy jest późniejsze; okna „wcinają się” w wysklepki, poza tym otwory w ścianie północnej i południowej różnią się kształtem, natomiast na poddaszu widać zamurowane wnęki wychodzące ponad obecne wysklepki. 


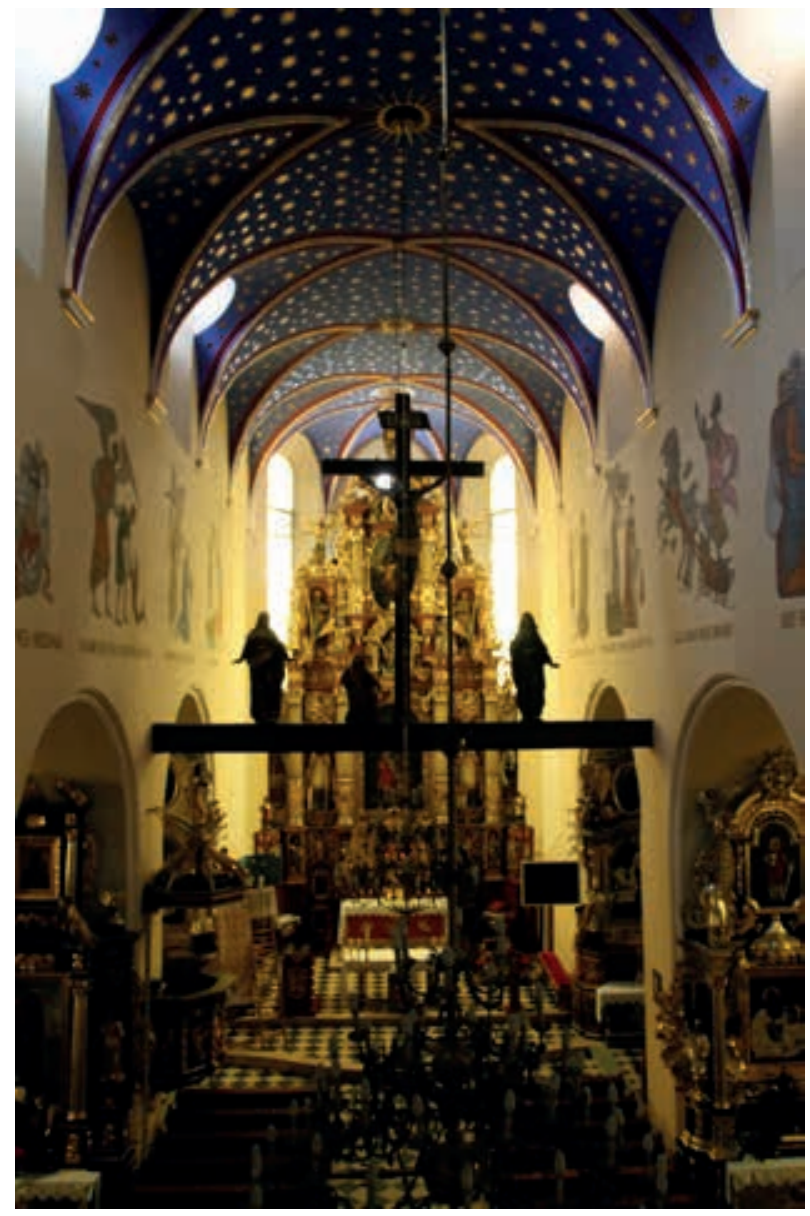

2. Kościół parafialny w Krotoszynie, widok nawy głównej ku wschodowi, koniec XVI w., fot. W. Miedziak

\section{FUNDACJE HIERONIMA ROZDRAŻEWSKIEGO}

Hieronim Rozdrażewski, stryjeczny brat Jana z Krotoszyna, w roku 1582, a więc w wieku 36 lat, objął włocławski stolec biskupi ${ }^{13}$. Jak przystało na wysokiego hierarchę kościelnego, wzniósł szereg świątyń, spośród których na uwagę zasługują przede wszystkim murowane kościoły parafialne w Raciążku (il. 3, 4), Pieniążkowie (il. 5, 6), Rozdrażewie (il. 7) i Łagowie. Najbardziej mo-

${ }^{13}$ H. Kowalska, [hasło:] Rozdrażewski (Rozrażewski) Hieronim h. Doliwa, w: PSB, 1989-1991, 31, s. 355-365, tu: s. 357. 
numentalną fundacją był kościół w Raciążku, wybudowany w ośrodku dóbr biskupich, między latami 1597-1612 ${ }^{14}$.

Podobnie jak fara krotoszyńska jest to świątynia o przeważających cechach gotyckich z nowożytnymi detalami. Składa się na nią wysoki, czteroprzęsłowy korpus poprzedzony potężną wieżą artykułowaną licznymi blendami (il. 3), w której znalazło się ogrzewane pomieszczenie, być może mieszkalne. Nawa,

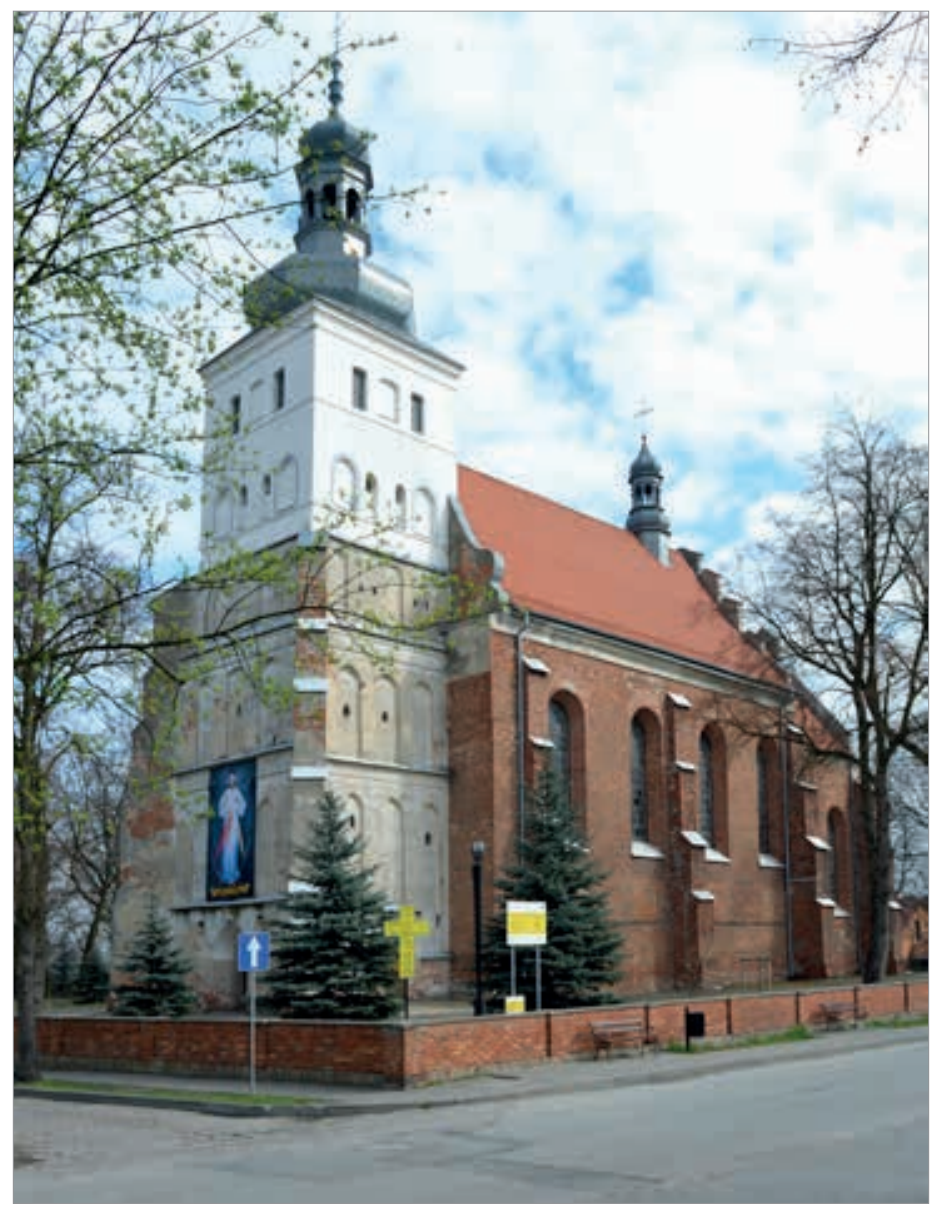

3. Kościół parafialny w Raciążku, widok od południowego zachodu, 1597-1612, fot. W. Miedziak

14 T. Chrzanowski, Czyżby spuścizna po katedrze płockiej?, w: Nobile claret opus. Studia z dziejów sztuki dedykowane Mieczysławowi Zlatowi, red. L. Kalinowski et al., Wrocław 1998, s. 243. 
pierwotnie doświetlona wysokimi, ostrołukowymi oknami, łączy się z nieco niższym, prostokątnym chórem zamkniętym absydą (il. 4). Do prezbiterium od północy przylega zakrystia z wyniosłą, dwuprzęsłową emporą ${ }^{15}$.

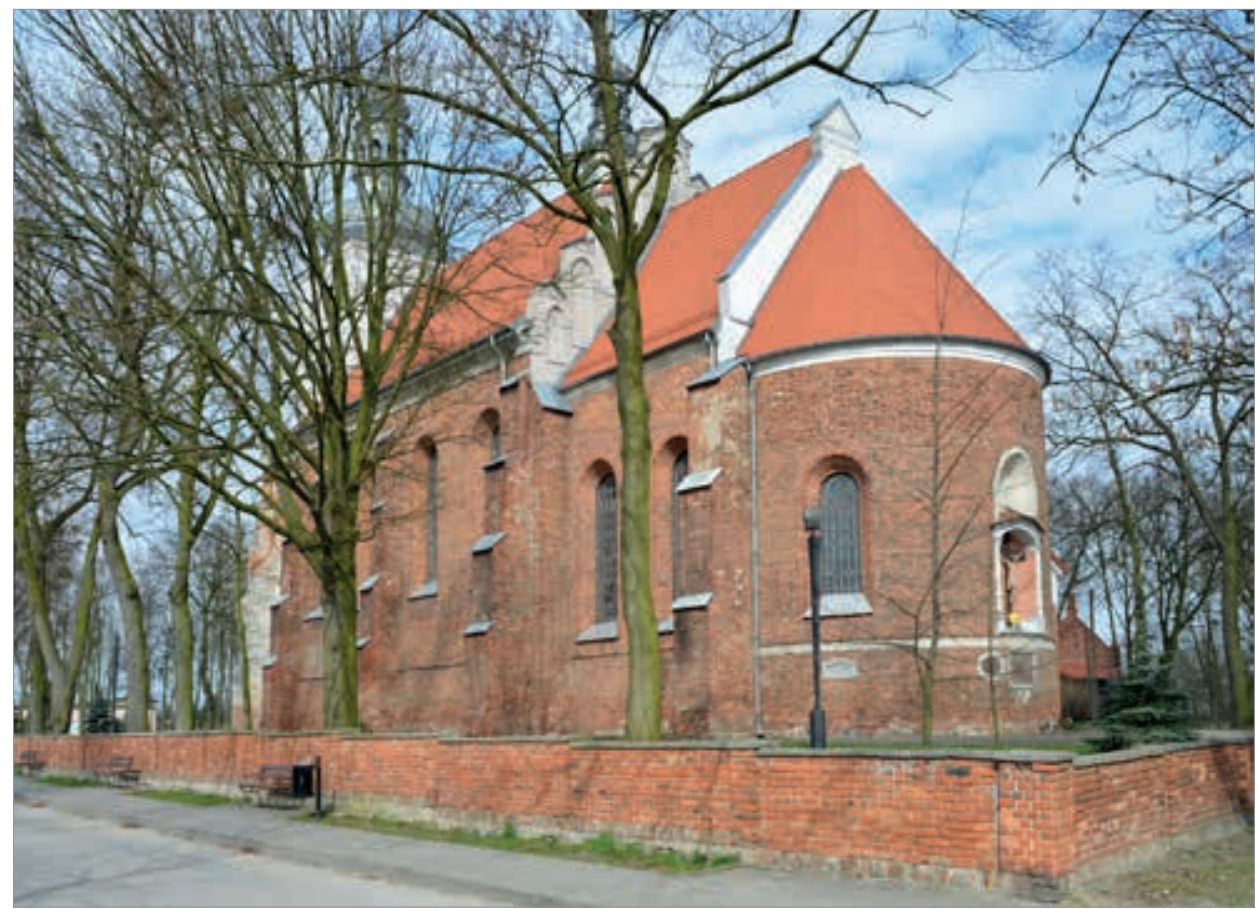

4. Kościół parafialny w Raciążku, widok od południowego wschodu, 1597-1612, fot. W. Miedziak

W architekturze świątyni da się zaobserwować interesujące połączenie elementów gotyckich i nowożytnych; okna w absydzie miały pierwotnie wykrój ostrołukowy ${ }^{16}$, zaś wschodni szczyt korpusu dekorują ostrołukowe blendy zamknięte w nowożytnych edykułach.

${ }^{15}$ Wnętrze kościoła jest nakryte sklepieniami, pochodzą one jednak z XX wieku (por. ibidem, s. 245-246). O kościele w Raciążku zob. także: Gryglewski, De sacra antiquitate, s. 316-318; idem, Oddziaływanie nowożytnej katedry płockiej na przemiany w polskiej architekturze sakralnej w XVI w. - uwag kilka, w: Sztuka Polski środkowej-studia, t. V, red. K. Stefański, P. Gryglewski, Łódź 2011, s. 27-47, tu: s. 33, 35, 38-39.

16 Obecnie ostrołukowe jest tylko okno na osi kościoła, dwa boczne zostały przemurowane. 
Świątynię w Pieniążkowie (il. 5, 6) wzniesiono między rokiem 1590 a 1593 sumptem Hieronima Rozdrażewskiego i Jana Oleskiego, późniejszego podkomorzego koronnego i pomorskiego ${ }^{17}$. Charakteryzuje ją szczególnie bogata dekoracja płycinowa, pojawiająca się bez mała na wszystkich elewacjach - na trójbocznie zamkniętym, opiętym przyporami prezbiterium, na nieco szerszej od niego prostokątnej w rzucie nawie i niewysokiej

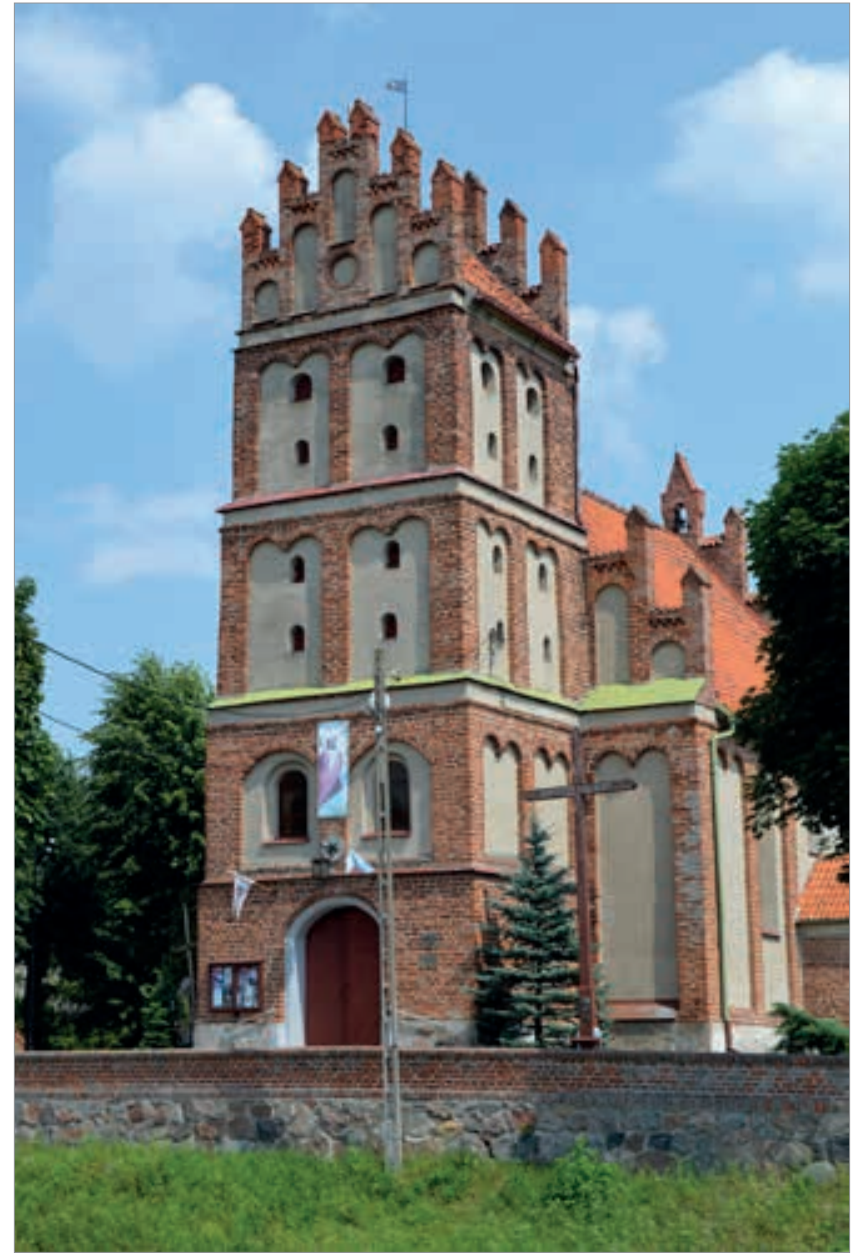

5. Kościół parafialny w Pieniążkowie, widok wieży od południowego zachodu, ok. 1590-1593, fot. W. Miedziak

${ }^{17}$ Katalog Zabytków Sztuki w Polsce (dalej: KZSP) XI, Województwo bydgoskie, 15, Powiat świecki, oprac. T. Chrzanowski, T. Żurkowska, Warszawa 1970, s. 32. 


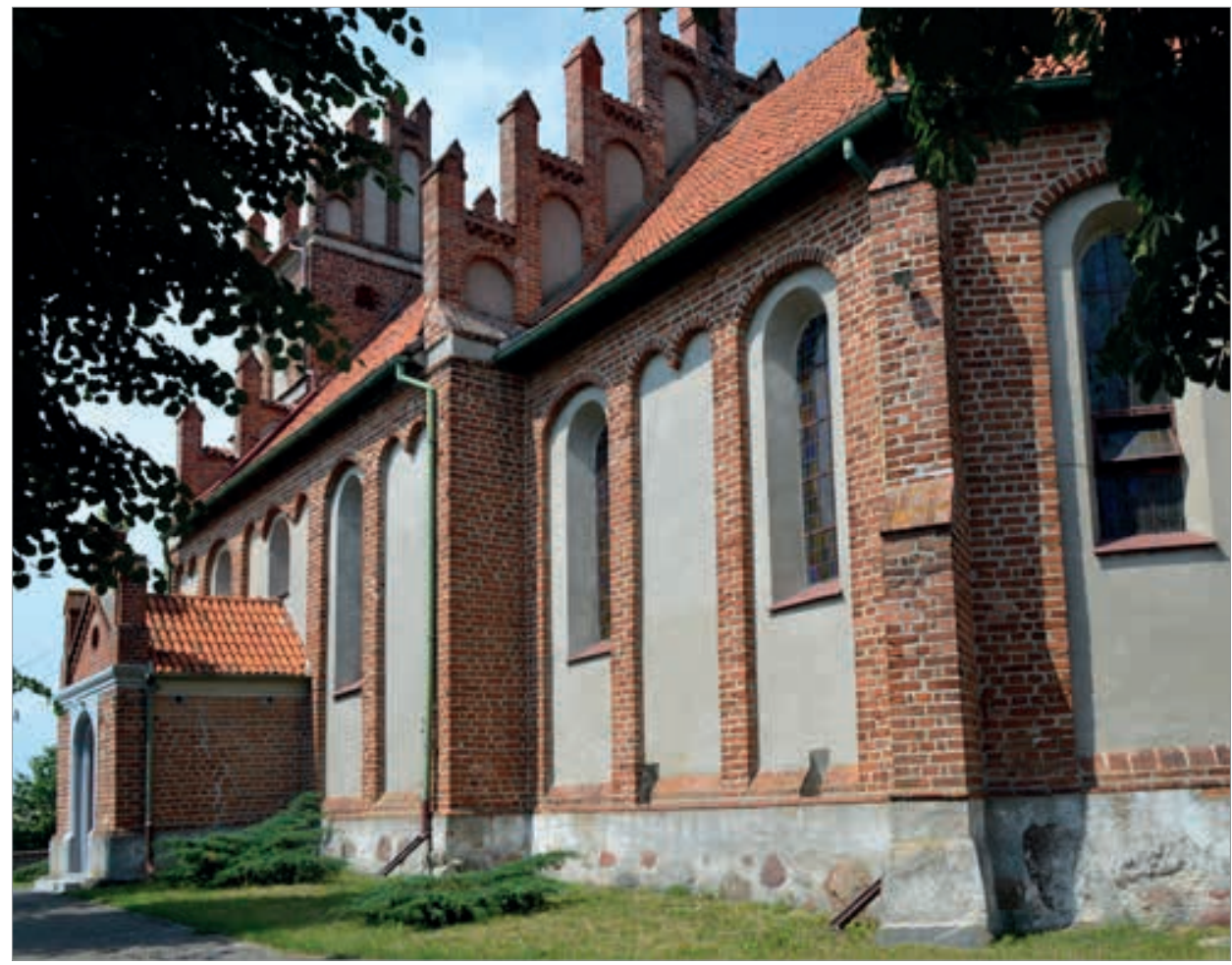

6. Kościół parafialny w Pieniążkowie, widok od południowego wschodu, ok. 1590-1593, fot. W. Miedziak

zachodniej trójkondygnacyinej wieży. Blendy tworzą równocześnie system eleganckich, opinających wszystko lizen, które wychodzą ze strefy cokołowej, wybudowanej z wielkich ciosów kamiennych. U korony murów lizeny łączą dwu- i trójłucza, sprowadzone do formy arkadkowego fryzu. W całym kościele, mimo zagęszczenia płycin i otworów, w ogólne nie pojawiają się ostrołuki. Wszystkie blendy, otwory okienne i wejściowe, zamurowane arkadki szczytu i arkada tęczowa, zamknięte są łukami pełnymi (lub niekiedy odcinkowymi) ${ }^{18}$.

${ }_{18}$ Nie jest mi znana inna budowla szesnastowieczna (może poza katedrą płocką) z podobnym zagęszczeniem pozornych i prawdziwych otworów, w której ani razu nie pojawia się ostrołuk. 
Do fundacji biskupa Hieronima należy także fara w rodzinnym gnieździe Rozdrażewskich - Rozdrażewie (il. 7). Kościół został konsekrowany w roku 1644, zatem na długo po śmierci fundatora, jednak nie ulega wątpliwości, z czyjego legatu został wzniesiony ${ }^{19}$. Źródła milczą co do początku budowy; szczęśliwie świątynię przed dziewiętnastowieczną przebudową odwiedził Julius Kohte, który zanotował, że na belce tęczowej widnieje data „1617"20. Moż-

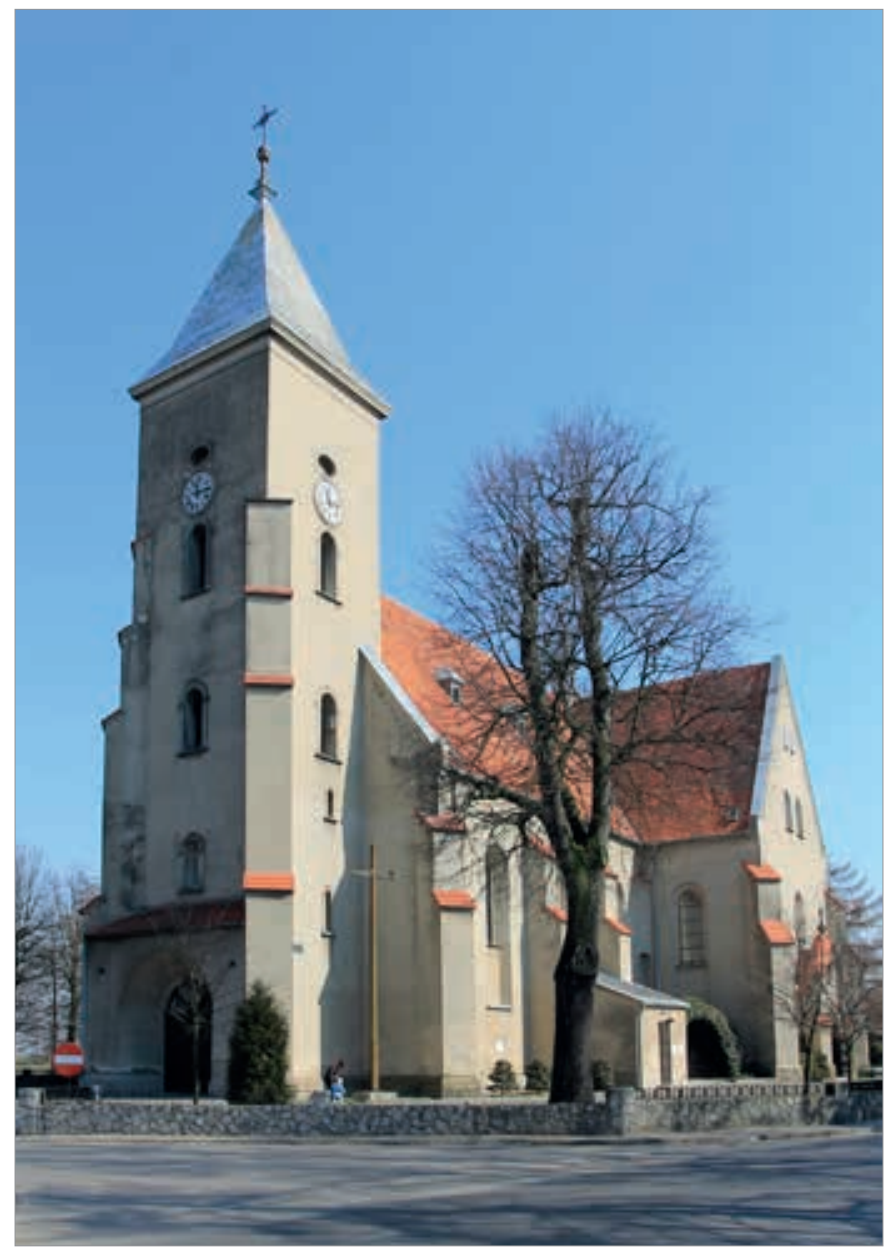

7. Kościół parafialny w Rozdrażewie, widok od południowego zachodu, pierwsza ćwierć XVII w., fot. W. Miedziak

19 J. Kohte, Verzeichnis der Kunstdenkmäler der Provinz Posen, t. 3, Berlin 1898, s. 315.

20 Ibidem. 
na więc przyjąć, że do tego czasu kościół musiał stać już w zasadniczej części. Po śmierci Hieronima Rozdrażewskiego budowy doglądała rodzina, w osobach syna i wnuka dysydenta Jana Rozdrażewskiego z Krotoszyna - Jana i Jakuba ${ }^{21}$.

Świątynia nie dotrwała do naszych czasów w pierwotnej formie - w roku 1899 rozebrano dawne trójbocznie zamknięte prezbiterium wraz z aneksem zakrystii od północy i do jednonawowego korpusu poprzedzonego wieżą dobudowano nowy transept oraz nowe prezbiterium ${ }^{22}$. W trakcie rozbudowy kościół został w całości otynkowany - ujednolicono przy tym okna i jednouskokowe przypory, stąd też trudno wyrokować o ich dawnym kształcie. W nawie głównej korpusu zachowały się sklepienia kolebkowe z lunetami i wąskimi żebrami ${ }^{23}$. Sklepienia te zasługują na szczególną uwagę ze względu na plakiety umieszczone w miejscu zworników. Dekorowane są one motywami bardzo podobnymi do prefabrykatów używanych przez sztukatora Jana Wolffa, uważanego za „najbardziej wyrazistą osobowość artystyczną lubelsko-zamojskiej architektury cechowej" ${ }^{\prime 24}$.

Interesująco na tle fundacji Hieronima Rozdrażewskiego wypada dzieło rozbudowy kościoła pw. św. Michała Archanioła w Łagowie. Pierwotnie była to świątynia $z$ kamiennym, sklepionym krzyżowo, dwuprzęsłowym prezbiterium oraz drewnianą nawą, wzniesiona około roku 1470. Po rozebraniu nawy w latach ok. 1581-1600 z legatu biskupa dobudowano korpus, tj. nawę główną i kaplice, stanowiące rodzaj naw bocznych, oraz wieżęę․ Nawę główną nakryto sklepieniami gwiaździstymi czteroramiennymi z wpisaną gwiazdą ośmioramienną, kaplice sklepieniami gwiaździstymi czteroramiennymi ${ }^{26}$. Nad kaplicą południową pojawił się jednak nowożytny szczyt ${ }^{27}$.

${ }^{21}$ Stanisław Kozierowski błędnie podaje, że Jan i Jakób Rozdrażewscy - ojciec i syn byli braćmi, por. idem, Szematyzm historyczny ustrojów parafialnych..., s. 350.

22 Ibidem.

${ }^{23}$ Takimi samymi sklepieniami był też najpewniej nakryty chór, zob. Kohte, Verzeichnis der Kunstdenkmäler..., s. 315.

${ }^{24}$ M. Kurzei, Jan Wolff. Monografia architekta $w$ świetle analizy prefabrykowanych elementów dekoracji sztukatorskich, Kraków 2009, s. 69.

${ }^{25}$ KZSP III, Województwo kieleckie, 7, Powiat opatowski, red. J.Z. Łoziński, B. Wolff, Warszawa 1959, s. 31-32.

26 J. Kowalski, Gotyk wielkopolski, Poznań 2010, s. 363-364.

${ }^{27}$ Piotr Gryglewski pozostawia nowożytne formy tegoż szczytu na uboczu swoich rozważań, skupiając się na gotyckich sklepieniach nawy i traktując je jako nawiązujące do piętnastowiecznych sklepień prezbiterium, co ma być przykładem „renowacji” (por. Gryglewski, De sacra antiquitate, s. 320-321). W istocie nić stylistyki architektonicznej łącząca piętnastowieczne prezbiterium i szesnastowieczny korpus nie zostaje przerwana. Gotyckie sklepienia w okolicy kościoła łagowskiego nie należały w tym czasie do rzadkości (por. Zaucha, Tradycja gotycka $w$ architekturze sakralnej..., passim). 


\section{FUNDACJE JANA ROZDRAŻEWSKIEGO-NOWOMIEJSKIEGO}

Kościół grabienicki (il. 8) został erygowany w roku 1597. Wzniósł go Jan Rozdrażewski-Nowomiejski, sufragan włocławski, dalszy kuzyn Hieronima Rozdrażewskiego ${ }^{28}$. Data fundacji świątyni została zapisana na szczęśliwie zachowanej tablicy erekcyjnej, na której wskazana jest osoba fundatora i fakt budowy kościoła od podstaw ${ }^{29}$.

Kościół składa się z dwóch zasadniczych członów - wzniesionej na rzucie zbliżonym do kwadratu nawy i nieco węższego od niej prezbiterium o podobnych proporcjach. Chór graniczy od północy z przybudówką zakrystii, z którą nakryty jest wspólnym dachem, od wschodu zaś dostawiono doń niewielki prostokątny aneks. Jest to zapewne pozostałość po stojącej tu wcześniej absydzie ${ }^{30}$. Okna świątyni są stosunkowo krótkie, w nawie zakończone łukiem pełnym, w prezbiterium zaś - odcinkowym. Kościół jest w całości tynkowany, stąd też trudno określić ich pierwotną formę.

Na szczególną uwagę zasługują szczyty świątyni - zachodni i wschodni. Zachodni, o formie analogicznej do szczytu kaplicy fary łagowskiej, „zamyka” nawę nakrytą stropem, pod którym tkwią ostrołukowe opory sklepienne - mamy tu zatem analogiczną względem kościoła w Łagowie sytuację - nad projektowanym sklepieniem gotyckim pojawia się, co prawda oszczędny w formie, ale z pewnością nowożytny szczyt. Z kolei prezbiterium, także nakryte stropem, ma opory sklepienne o łukach pełnych, zatem projektowano tu sklepienia „nowożytne” (być może krzyżowe). Zamyka je jednak szczyt gotycki - czy raczej gotycko-nowożytny (il. 8). Jest to szczyt złożony z trzech blend zamkniętych dwułuczem, z wyższą wnęką na osi oraz umieszczonych u jego podstawy dwóch „serii” okulusów, połączonych rzędem i zgrupowanych w dwa poziomy. Do szczytu wschodniego kościoła należy zaliczyć też szczyt zakrystii, złożony z dwóch analogicznych blend, dekorowanych dodatkowo okulusem umieszczonym nad dwułucznym zamknięciem.

${ }^{28}$ W. Kujawski, [hasło:] Rozdrażewski (Rozrażewski) Nowomiejski Jan h. Doliwa, w: PSB, 1989-1991, 31, s. 373-374, tu: s. 374.

${ }^{29}$ Napis głosi: „HOC TOTUM OPUS ECCLESIE EX FUNDAMENTIS CONSTRUERE FECIT IOANNES ROZDRAZEWSKY INDIGNUS SACERDOS TE S CHR AD 1597”.

${ }^{30}$ Wskazują na to dwa fakty: po pierwsze - ściany północna i południowa aneksu „schodzą się" ku wschodowi, po drugie - dolne partie dekoracji szczytu (okulusy) są przerwane na jego osi, co sugeruje pozostawienie miejsca na spadzisty dach absydy. 


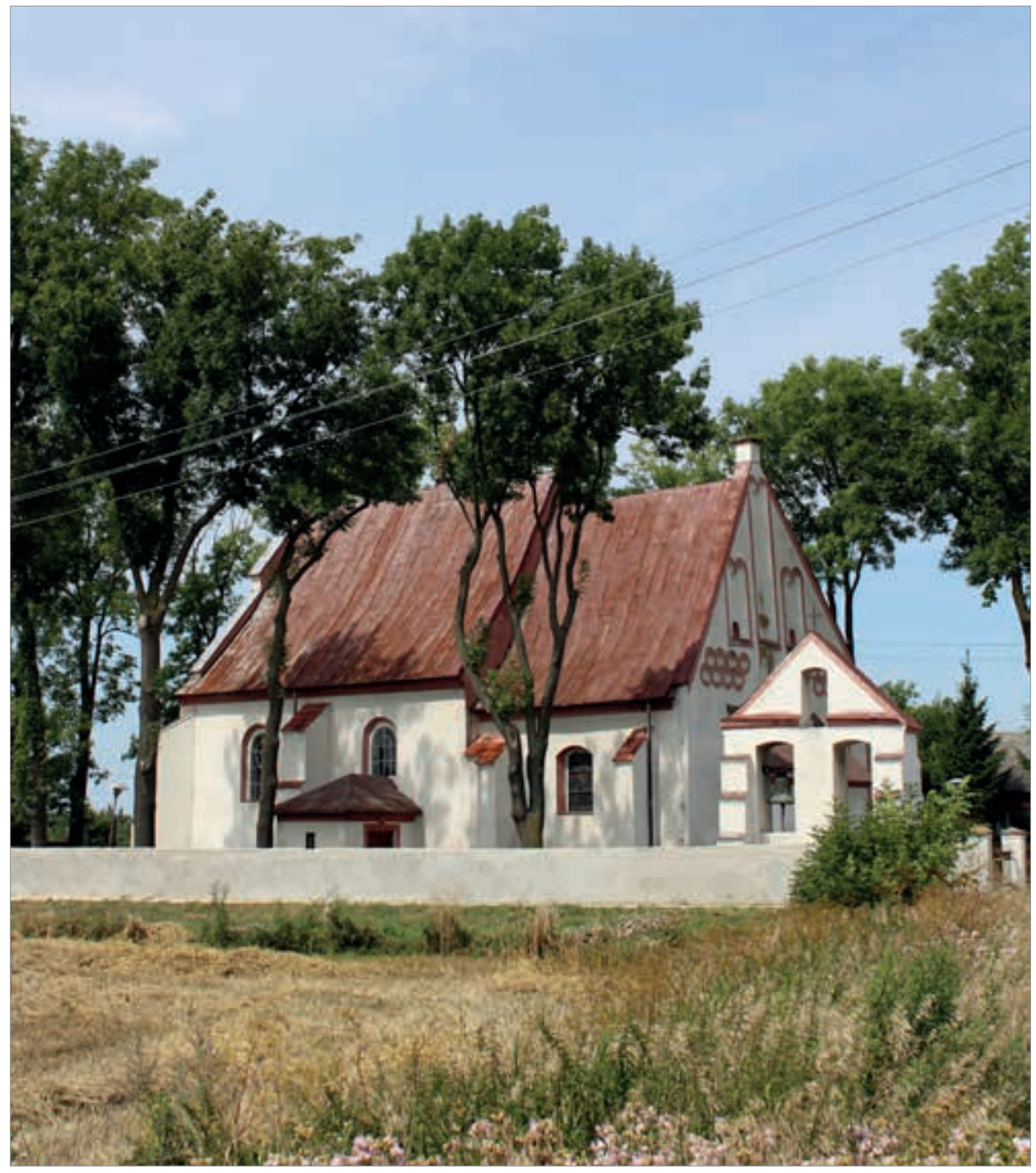

8. Kościół parafialny w Grabienicach, widok od północnego wschodu, ok. 1597, fot. W. Miedziak

Inspiracją dla form szczytu wschodniego w Grabienicach mogły być szczyty świątyń bydgoskich: przede wszystkim szczyt kaplicy południowej kościoła bernardynów, na którym pojawiają się serie okulusów, oraz szczyt fasady z płycinami zamkniętymi dwułuczem, między którymi umieszczono szczelinową blendę. Blendy zakończone prostym dwułuczem pojawiają się także na szczycie bydgoskiej świątyni klarysek. 
Działalność fundacyjna Jana Rozdrażewskiego-Nowomiejskiego objęła także rodzinną farę w Nowym Mieście nad Wartą ${ }^{31}$. Fundacja, nieco wcześniejsza od grabienickiej, pochodząca z roku 1593, została upamiętniona za pomocą inskrypcji umieszczonej pod ozdobnym kartuszem $z$ herbem Doliwów, wiszącym w blendzie okiennej południowej kaplicy. W tekście epigrafu nie zaznaczono, co zostało ufundowane; pojawia się jedynie lakoniczne "STRUXIT”, które może odnosić się zarówno do wybudowania nowej kaplicy, jak i wyposażenia czy „uporządkowania” starej $^{32}$.

\section{FUNDACJA ANNY Z ŁUKOWA ROZDRAŻEWSKIEJ}

Kościół w podkrotoszyńskich Benicach wystawiła Anna z Łukowa Rozdrażewska - matka dysydenta Jana Rozdrażewskiego, katoliczka. Jest to kościół niewielki, co nie przeszkodziło fundatorce zrealizować programu „pańskiej świątyni”; mamy tutaj zachodnią wieżę górującą nad jednonawowym, tróiprzęsłowym korpusem, do którego od wschodu przylega trójbocznie zamknięty chór wraz z północnym aneksem zakrystii. Wnętrze kościoła sklepiono analogicznie do fary rozdrażewskiej, jednak bez renesansowego detalu. Detal pojawia się dopiero na wschodnim, manierystycznym, szczycie korpusu.

Wypada w tym miejscu zwrócić uwagę na związek kościołów benickiego i rozdrażewskiego; obydwa wykańczał Jakub Rozdrażewski - prawnuk Anny

31 Oprócz tego nie można wykluczyć, że Rozdrażewski fundował także, lub może przebudował, kościół farny w Margoninie, miasteczku odkupionym od Jakuba Rokossowskiego w roku 1581 (por. D. Konieczka-Śliwińska, Dzieje Margonina w dobie staropolskiej, w: Dzieje Margonina, red. K. Rzepa, Poznań 2002, s. 27-51, tu: s. 50). Świątynia ta została jednak na tyle przebudowana w XVIII wieku, że nie sposób dziś wnioskować o jej pierwotnej formie, natomiast w źródłach brak precyzyjnego datowania. Wszelako w literaturze pojawiają się informacje, jakoby kościół wznieśli Rozdrażewscy (po Janie Rozdrażewskim-Nowomiejskim miejscowość odziedziczył kasztelan międzyrzecki Hieronim Rozdrażewski); por. Kowalski, Gotyk wielkopolski, s. 446, przyp. 170 - tam dalsza literatura.

32 Jakub Adamski dowodzi, że treść tablicy, umieszczonej obecnie na murach kaplicy południowej, dotyczy fundacji tej właśnie kaplicy. Miała być ona, zdaniem autora, planowanym miejscem spoczynku Jana Rozdrażewskiego-Nowomiejskiego (por. J. Adamski, Uwaga na temat datowania kaplic przy farze w Nowym Mieście nad Warta, w: Sztuka w Wielkopolsce, red. M. Błaszczyński, B. Górecka, M. Górecki, A. Paradowska, Poznań 2013, s. 2231). Trzeba jednak zauważyć, że tablica została skądś przeniesiona i wmurowana w blendę okienną wtórnie (o czym świadczą m.in. jej wyszczerbione brzegi), zaś słowo „STRUXIT”, jak wspomniałem w głównym tekście, jest wieloznaczne. Wydaje się też, że lepszym miejscem spoczynku byłby wzniesiony przez Rozdrażewskiego w roku 1597 kościół grabienicki. 
z Łukowa, a konsekrował je w tym samym roku i miesiącu, dzień po dniu (Rozdrażew - 6 listopada 1644, Benice - 7 listopada 1644) sufragan gnieźnieński Jan Bajkowski ${ }^{33}$. Formy świątyń były niemal identyczne - w obydwu zastosowano wysoką wieżę, opięty jednoskokowymi przyporami korpus, trójbocznie zamknięte prezbiterium, aneks zakrystyiny od północy i system sklepień wspartych na przyściennych filarach. W prostej linii kościoły dzieli 10 kilometrów, więc mógł je wznosić jeden warsztat - nie wiadomo tylko, który z nich ukończono jako pierwszy. Wiadomo, że fundatorka świątyni w Benicach, Anna z Łukowa, została w niej pochowana ${ }^{34}$, co pozwala sądzić, że w końcu XVI wieku, kiedy zmarła, stało już przynajmniej prezbiterium.

\section{ARCHITEKTURA GOTYCKA PRZEEOMU XVI I XVII WIEKU W LITERATURZE}

W literaturze rozważania na temat architektury o cechach gotyckich na przełomie wieków XVI i XVII koncentrują się zwykle wokół koncepcji kontynuowania przez ówczesnych rozwiązań gotyckich lub świadomego powrotu do nich ${ }^{35}$. W wypadku pierwszej interpretacji gotyk w nowożytności jawi się jako naturalny etap rozwoju architektury, "styl” aktualny i akuratny dla swojej epoki ${ }^{36}$. W drugiej podkreśla się możliwości celowej archaizacji za pomocą form gotyckich, przy czym ów zwrot ku przeszłości zwykle uzasadniany jest chęcią legitymizacji, m.in. prawowierności czy odwieczności rodu ${ }^{37}$. Niekie-

${ }^{33}$ Zob. J. Łukaszewicz, Krótki opis historyczny kościołów parochialnych, kościółków, kaplic, klasztorów, szkółek parochialnych, szpitali i innych zakładów dobroczynnych w dawnej dyecezyi poznańskiej, t. 2, Poznań 1859, s. 150-153. W przypadku kościoła w Rozdrażewie Józef Łukaszewicz przez pomyłkę jako rok konsekracji podał 1664 (ibidem, s. 150).

${ }^{34}$ Ibidem, s. 152.

35 Gryglewski, De sacra antiquitate, s. 257. Trudno stwierdzić, która z tych dwóch tez ostatecznie zyskała większe grono zwolenników, zwłaszcza że dyskusja toczyła się nie tylko w Polsce, ale też w Niemczech czy we Francji; por. stan badań przedstawiony przez autora (ibidem, s. 257-270).

${ }^{36}$ Tak m.in. E. Panofsky (Das erste Blatt aus dem „Libro” Giorgio Vasaris. Eine Studie über die Beurteilung der Gotik in der italienischen Renaissance (mit einem Exkurs über zwei Fassadenprojekte Domenico Beccafumis), „Städel-Jahrbuch” 1930, 6, s. 26-72) oraz H. Hipp (Studien zur „Nachgotik” des 16. und 17. Jahrhunderts in Deutschland, Böhmen, Österreich und der Schweiz, Tübingen 1979, passim).

${ }^{37}$ Tak m.in. B. Schock-Werner, Die Bauten im Fürstbistum Würzburg unter Julius Echter von Mespelbrunn. Struktur, Organisation, Finanzierung und künstlerische Bewertung, Regensburg 2005, s. 55-57, 78-79; Gryglewski, De sacra antiquitate, passim. 
dy badacze wskazują na możliwość równoczesnego trwania gotyku i powrotu do niego, przy czym trwanie dotyczy zwykle kontynuowania tradycji warsztatowych w budownictwie prowincjonalnym, świadomy powrót zaś łączy się z wielkimi fundacjami, np. znacznych osobistości ${ }^{38}$.

W kontekście niniejszego tekstu interesująca jest argumentacja badaczy przypisujących ówczesnej architekturze właściwości archaizacyjne, uzasadnione domniemanym współzawodnictwem katolików i innowierców na polu prawowierności ${ }^{39}$. Gotycka forma świątyń miała być używana „przez obie strony sporu, jako argument dowodzący łączności z wielowiekową, "pierwotną" tradycją Kościoła" ${ }^{\prime 4}$. Według innego wariantu tej tezy, formy gotyckie miały być efektem „antypapizmu” innowierców (i nie tylko innowierców), wyrażającego się odrzucaniem włoskiej architektury na rzecz rozwiązań tradycyjnych ${ }^{41}$.

\section{INTERPRETACJA FUNDACJI ROZDRAŻEWSKICH}

Pochodną rozważań metodologicznych jest cały szereg terminów funkcjonujących w literaturze, określających świątynie o cechach gotyckich powstające na przełomie wieków XVI i XVII: od „późnogotycki”, przez „gotycko-renesansowy", "gotyk barokowy", "budowany w tradycjach gotyckich", „postgotycki”, „pogotycki”, „pseudogotycki”, „gotycyzujący” czy wreszcie mianem „neogotyku około roku 1600"42. Przegląd architektury wielkopolskiej

38 Tak M. Schmidt, Reverentia und Magnificentia. Historizität in der Architektur Süddeutschlands, Österreichs und Böhmens vom 14. bis 17. Jahrhundert, Regensburg 1999, passim; H. Rousteau-Chambon, Le gothique des Temps modernes. Architecture religieuse en milieu urbain, Paris 2003, s. 98-119; w podobnym tonie także T. Chrzanowski ( „Neogotyk około 1600" - próba interpretacji, w: Sztuka około roku 1600. Materiały Sesji SHS, Lublin, listopad 1972, Warszawa 1974, passim).

${ }^{39} \mathrm{Na}$ dominację tej argumentacji zwrócili uwagę K.J. Czyżewski i M. Walczak (por. iidem, O średniowiecznych wzorach nowożytnych kościołów z kaplicami „in modum crucis" na ziemiach Rzeczypospolitej, w: Sztuka dawnej ziemi chełmińskiej i województwa bełskiego, red. P. Krasny, Kraków 1999, s. 25-49, tu s. 35). Sama teza pojawiła się natomiast po raz pierwszy w Niemczech, por. ibidem, s. 35, przyp. 41 - tam stan literatury.

40 Ibidem, s. 35.

${ }^{41}$ P. Krasny, „estem katolikiem a nie papista”. Świadomość konfesyjna fundatorów a problem prowincjonalizmu architektury sakralnej w Europie środkowej około roku 1600, w: Centrum, prowincje, peryferia. Wzajemne relacje w dziejach sztuki, red. P. Gryglewski, K. Stefański, R. Wróbel, Łódź 2013, s. 69-91.

${ }^{42}$ Krótkie omówienie części tej terminologii przedstawia Grażyna Jurkowlaniec, por. eadem, Epoka nowożytna wobec średniowiecza. Pamiq̨tki przeszłości, cudowne wi- 
XVI i XVII wieku utwierdza mnie w przekonaniu, że pojęcia te, choć obejmują różne przedziały czasowe, dotyczą w gruncie rzeczy jednego, szerszego zjawiska. Polega ono na posługiwaniu się przez budowniczych i architektów formami wywodzącymi się z tradycji gotyckiej w czasie, kiedy znane są już formy nowożytne. Określeniem adekwatnym dla tego zjawiska, bo możliwie ogólnym, jest termin „gotyk nowożytny"43.

Jest to zjawisko niejednorodne, zarówno w stosowanych formach, jak i przyczynach ich stosowania, co w pewnym stopniu wyjaśnia wielość propozycji terminologicznych i różne ujęcia problemu w literaturze. W wielkopolskich świątyniach „gotycko-nowożytnych” można wydzielić cztery podstawowe - i jak się wydaje równoczesne - tendencje: (1) stosowanie rozwiązań czysto gotyckich, (2) przetwarzanie (rozwój) form gotyckich, (3) kompilacja kształtów gotyckich z nowożytnymi (co znajduje odbicie zarówno w technice budowlanej, jak i detalu) oraz (4) stosowanie form czysto nowożytnych, które w kontekście gotyckiej struktury architektonicznej stwarzają wespół z nią nową jakość artystyczną.

Co do zasięgu czasowego występowania takiej architektury trudno o wyznaczanie precyzyinej chronologii. Najpopularniejsze pojęcia (postgotyku, pogotyku etc.) badacze odnoszą z reguły do "architektury około roku 1600”, co wynika $z$ tradycyjnego, choć w moim mniemaniu zupełnie sztucznego, zawężania problematyki. W Wielkopolsce "gotyk nowożytny" pojawia się około pierwszej tercji XVI wieku ${ }^{44}$ i dominuje do końca stulecia, ustępując miejsca manieryzmowi czy barokowi dopiero w drugiej ćwierci wieku XVII. Ta dominacja jest niemal absolutna, jednak ogólnie nieuświadamiana - mało kto

zerunki, dzieła sztuki, Wrocław 2008, s. 29. Terminu „pogotyk” używa np. Gryglewski, por. idem, De sacra antiquitate, s. 257 i dalej; określenia „budowany w tradycjach gotyckich” czy "gotycko-renesansowy” pojawiają się często w notach katalogowych (por. np. KZSP XI, Województwo bydgoskie, 3, Bydgoszcz i okolice, oprac. T. Chrzanowski, M. Kornecki, Warszawa 1977, s. 16, 35, 55; KZSP XI, Województwo bydgoskie, 1, Powiat aleksandrowski, oprac. J. Frycz, T. Chrzanowski, M. Kornecki, Warszawa 1969, s. 35), także w syntezach (np. T. Dobrowolski, Sztuka polska, Kraków 1974, s. 268 nn.). Na temat „fenomenu” architektury około roku 1600 osobny tekst napisał Tadeusz Chrzanowski, por. idem, „Neogotyk około $1600 "$..., s. 83/84.

${ }^{43}$ Termin ten „wynalazła” Hélène Rousteau-Chambon; por. eadem, Le gothique des Temps modernes. W toku swojego wywodu, choć nie „programowo”, posługiwał się nim także Tomasz Zaucha; por. Zaucha, Tradycja gotycka $w$ architekturze sakralnej..., s. 13. Pojawia się ono także w książce Piotra Gryglewskiego (przy odwołaniu autora do tez Hubertusa Günthera; zob. niżej, przyp. 13), zob. Gryglewski, De sacra antiquitate, s. 216.

${ }^{44}$ Wnioski tutaj przedstawione są efektem badań terenowych prowadzonych przeze mnie od roku 2014. Wczesne i dość nieśmiałe próby „reakcji” na renesans możemy obserwować głównie w szczytach kościołów - np. w Stawie czy Wilkowie Polskim. 
chyba zdaje sobie sprawę $z$ faktu, że do końca XVI wieku nie wybudowano w tym regionie ani jednej świątyni, którą uznać by można za konsekwentnie nowożytną, zrywającą z budownictwem gotyckim. Nowożytne tendencje w architekturze tego czasu znajdują ujście jedynie w małych formach budowlanych, takich jak kaplice grobowe ${ }^{45}$.

Fundacje architektoniczne Rozdrażewskich dobrze egzemplifikują wieloraki charakter gotyku nowożytnego, równocześnie też dają możliwość polemiki z niektórymi tezami pojawiającymi się w literaturze. Fara w Krotoszynie może służyć za przykład protestanckiej świątyni budowanej w tradycjach gotyckich, w której pierwiastek gotycki nie musi wcale dowodzić „łączności z wielowiekową, "pierwotną" tradycią Kościoła".

Bracia czescy, do których przynależał Jan Rozdrażewski, przybyli do Korony z Królestwa Czech w roku $1548^{46}$. W tym czasie Jednota, która wyrosła z ruchów husyckich około połowy XV wieku, legitymizowała się już niemal stuletnią tradycią ${ }^{47}$. Stąd też gotyckie kształty szesnastowiecznych świątyń braci czeskich, a w ich liczbie i fary krotoszyńskiej, nie stanowią prostego odwołania do średniowiecznej architektury katolickiej, ale mogą równie dobrze podejmować tradycje świątyń innowierczych (np. kaplicy betlejemskiej w Pradze ${ }^{48}$ ). Gotyckość protestanckich kościołów nie była zresztą regułą. Część innowierców odrzucała co prawda nowożytne kształty architektoniczne, o czym świadczą słowa Jana Niemojowskiego, „jednego z trybunów różnowierczej szlachty” ${ }^{49}$, który w roku 1583 mówił: „Nie mury lecz wierni są ozdobą świątyń, dlatego staramy się je budować na Chrystusie, odrzucając praktyki włoskie" ${ }^{50}$. Jednakże, jak wskazuje Jan Harasimowicz, nie było to praktyką ogólną, bowiem np. zbory austriackie (Murstetten, Sachsenfeld-Scharfeenau) na sposób włoski (tj. renesansowy) budowali Wło-

${ }^{45}$ Zob. np. M. Kurzej, Kościół parafialny pw. św. Małgorzaty Antiocheńskiej w Zborowie na Szaryszu. Przyczynek do dyskusji nad zjawiskiem postgotyku w Europie Środkowej, „Modus. Prace z Historii Sztuki” 2005, 5, s. 5-22, tu: s. 17.

${ }^{46}$ H. Gmiterek, Bracia czescy a kalwini w Rzeczypospolitej. Połowa XVI - połowa XVII wieku. Studium porównawcze, Lublin 1987, s. 6.

${ }^{47}$ Ibidem; zob. także: J. Dworzaczkowa, Bracia czescy w Wielkopolsce w XVI i XVII wieku, Warszawa 1997, s. 12.

48 A. Kubiček, Betlemská kaple, Praha 1953, s. 22-23.

${ }^{49}$ J. Harasimowicz, Fundacje sakralne różnowierczej szlachty polskiej w XVI i XVII wieku, w: Fundacje i fundatorzy w średniowieczu i w epoce nowożytnej, red. E. Opaliński, T. Wiśnicz, Warszawa 2000, s. 148.

${ }^{50}$ Cyt. za: A. Kossowski, Protestantyzm w Lublinie i na Lubelszczyźnie w XVI-XVII w., Lublin 1933, s. 46. 
$\mathrm{si}^{51}$. O kształcie wczesnonowożytnych świątyń protestanckich decydowały czynniki podobne tym, które wpływały na formy kościołów katolickich, m.in. możliwość pozyskania odpowiedniego architekta czy gusta fundato$\mathrm{ra}^{52}$. Sytuacja ta dotyczyła szczególnie polskich członków Jednoty Brackiej, odróżniającej się od czesko-morawskiej strukturą społeczną wyznawców podczas gdy w Czechach dominowali chłopi i mieszczanie, wspólnota polska była zdominowana przez szlachtę, która rozporządzała nieporównanie większymi środkami finansowymi ${ }^{53}$.

W XVI wieku w Rzeczypospolitej i na Śląsku nie ukształtował się żaden konkretny model świątyni innowierczej ${ }^{54}$; tendencje centralizujące, będące efektem dostosowywania architektury do kryteriów funkcjonalnych, nie były jeszcze zbyt silne ${ }^{55}$. Stąd też tradycyjna forma kościoła w Krotoszynie, mimo słusznych skojarzeń z budownictwem katolickim, nie powinna dziwić - w podobnym typie ( $z$ wyodrębnionym prezbiterium i wieżą od zachodu) wznoszono w tym czasie (i później!) świątynie innowiercze na Śląsku ${ }^{56}$.

Tradycja gotycka w formach fary krotoszyńskiej nie jest zresztą jedyną cechą wartą uwagi. Charakterystyczny jest jej rzut krzyżowy, z parą kaplic na przedłużeniu naw bocznych; jest to typ, na którego włoską genezę zwracał uwagę już Adam Miłobędzki, a który „zakorzenił się w Polsce od przełomu XVI i XVII wieku" ${ }^{57}$. Kościół w Krotoszynie jest więc jedną z wczesnych realizacji takiego modelu.

${ }^{51}$ Harasimowicz, Fundacje sakralne różnowierczej szlachty..., s. 148.

52 Ibidem, s. 147-148.

${ }^{53} \mathrm{Na}$ ten temat zob. Gmiterek, Bracia czescy a kalwini..., s. 62; także J. Harasimowicz, Treści i funkcje ideowe sztuki śląskiej reformacji: 1520-1650, Wrocław 1986, s. 23.

${ }^{54}$ Harasimowicz, Treści i funkcje ideowe..., s. 21. Da się wszakże wykazać wzajemne inspiracje w architekturze zborów różnych ziem Rzeczypospolitej. Dotyczy to m.in. świątyni w wielkopolskim Mórkowie inspirowanej zapewne formami zborów śląskich, por. Mittelalterliche Architektur in Polen. Romanische und gotische Baukunst zwischen Oder und Weichsel, t. 2, red. C. Herrmann, D. von Winterfeld, Petersberg 2015, s. 1147.

55 Zob. Harasimowicz, Fundacje sakralne różnowierczej szlachty..., s. 147. Wczesnym przykładem tych tendencji jest zbór w Oksie, wzniesiony krótko po połowie stulecia (por. P. Krasny, Zbór kalwiński w Oksie. Przyczynek do badań nad forma centralng w polskiej architekturze sakralnej XVI wieku, w: Magistro et Amico amici discipulique. Lechowi Kalinowskiemu w osiemdziesięciolecie urodzin, red. J. Gadomski, Kraków 2002, s. 258).

${ }^{56}$ Harasimowicz, Treści i funkcje ideowe..., s. 23.

57 Autor dokonał też istotnego rozróżnienia typu krzyżowego kościoła jednonawowego i bazylikowego; w pierwszym wypadku kaplice umieszczano symetrycznie po bokach, w drugim stanowiły one przedłużenie bocznych naw (por. A. Miłobędzki, Architektura polska XVII wieku, Warszawa 1980, s. 63). 
Podobne jak w farze krotoszyńskiej, połączenie tradycji gotyckiej i nowych tendencji w architekturze miało istotne znaczenie w kościele w Raciążku. Godny uwagi, obok rozwiązania formalnego absydy, tj. doświetlenia jej ostrołukami, jest sam fakt jej pojawienia się w kościele. Tadeusz Chrzanowski wymienił farę w Raciążku wśród świątyń z absydami, które mogły być „spuścizną po katedrze płockiej”58 (z czym należałoby się zgodzić), Piotr Gryglewski zaś sugerował skojarzenie tej formy z architekturą romańską $a^{59}$. Absydowe zamknięcie prezbiterium na terenie Polski środkowej można zatem rozumieć jako odniesienie do przeszłości - poprzez przywołanie formy romańskiej z obecnych na tych ziemiach kościołów (w Płocku, Tumie, Czerwińsku ${ }^{60}$ lub jako modną nowinkę, przyniesioną do kraju przez budowniczych włoskich (m.in. Jana Baptystę Wenecjanina), których obecność na tych ziemiach była silnie ugruntowana.

Wobec braku przekazów źródłowych trudno tutaj o rozstrzygnięcia w każdym razie absyda w kościele raciąskim przez gotyckie okna i osadzenie w kontekście gotyckich murów prezbiterium, korpusu i wieży tworzy nową jakość artystyczną - podobnie jak szczyt wschodni nawy, zgrabnie łączący ostrołuki z edykułami.

Kreatywnym podejściem do form gotyckich, przy jednoczesnym możliwym odniesieniu do form romańskich, odznacza się też kościół w Pieniążkowie. Tadeusz Chrzanowski twierdził, że jest to kościół „zbudowany [...] całkowicie jeszcze "po gotycku»"61, jednak inspiracji dla systemu blend zamkniętych podwójnym łukiem, pojawiających się na wszystkich elewacjach, możemy poszukiwać zarówno na wieżach szesnastowiecznych kościołów Prus, Pomorza, Mazowsza i Wielkopolski, jak i w zjawisku retrospektywnym, w tzw. późnogotyckim neoromanizmie ${ }^{62}$, znanym

58 Zob. Chrzanowski, Czyżby spuścizna po katedrze..., passim.

59 Piotr Gryglewski sugerował możliwość takiej interpretacji dla szerszej grupy szesnastowiecznych kościołów z absydami, zob. Gryglewski, Oddziaływanie nowożytnej katedry..., passim.

60 Taką interpretację wysunął m.in. T. Chrzanowski (Czyżby spuścizna po katedrze..., s. 246-247), traktując formy absydowe równocześnie jako świadectwo „opornego przyjmowania” form renesansowych i „niezupełnie uświadomioną” tendencję do nawiązywania do form romańskich. Podobnie pisał Piotr Gryglewski, skłaniając się jednak ku interpretacji o „uświadomionych” nawiązaniach do przeszłości (zob. Gryglewski, Oddziaływanie nowożytnej katedry..., s. 43-44 i nn.).

${ }^{61}$ Chrzanowski, Czyżby spuścizna po katedrze..., s. 251.

${ }^{62}$ Punktem odniesienia dla świątyni w Pieniążkowie mogą być też elewacje zewnętrzne Dworu Bractwa św. Jerzego w Gdańsku (niezależnie od tego, czy budynek ten rzeczywi- 
przede wszystkim ze sztuk plastycznych, ale i w ówczesnych dekoracjach renesansowych ${ }^{63}$. Tak czy inaczej, konsekwentna realizacja tego pomysłu wydaje się raczej rodzajem świadomego odwołania do form obecnych na tych ziemiach od dłuższego czasu, a więc „tradycyjnych”. Ich twórcze przetworzenie, podobnie jak zapożyczenie i przetworzenie dekoracji szczytu bydgoskich bernardynów w kościele grabienickim, pokazuje, że architektura gotycka miała na przełomie XVI i XVII wieku szansę na rozwój i że $z$ tej szansy korzystała.

Fundacje sakralne Hieronima Rozdrażewskiego wyczerpują zresztą praktycznie wszystkie sposoby podejścia do ówczesnej materii architektonicznej; obok kompilacji form gotyckich i nowożytnych, pojawiających się w Raciążku i Pieniążkowie, stosowano w nich także rozwiązania czysto gotyckie (sklepienia w Łagowie) oraz „wtłaczano” w repertuar gotyckiej architektury elementy nowożytne (Rozdrażew, Łagów, a także fundowane przez Annę Rozdrażewską Benice).

\section{FUNDACJE ROZDRAŻEWSKICH A KOŚCIOŁY WIELKOPOLSKIE PRZEŁOMU WIEKÓW XVI I XVII}

Fundacje sakralne rodziny Rozdrażewskich tworzą na przełomie wieków XVI i XVII dość silną liczebnie grupę. Ich cechą wspólną jest występowanie zachodniej wieży, co można traktować jako feudalny znak, charakteryzujący właścicieli ziemskich pochodzących ze starego rycerskiego rodu $^{64}$. Oprócz wież w świątyniach rodziny pojawia się także nowożytny detal - w formie renesansowych i manierystycznych szczytów, także w dekoracji sklepień, tablic erekcyjnych i nagrobnych. Zróżnicowanie w poziomie wykonania, a także niewielka reprezentacja tego detalu i różny czas powstania kościołów, skazuje na niepowodzenie próby powiązania zatrudnionych przez rodzinę warsztatów - z wyjątkiem świątyń w Rozdrażewie i Benicach. Można przypuszczać, że niezachowana do dziś absyda kościoła w Grabienicach była inspirowana absydą kościoła w Raciążku, na co wska-

\footnotetext{
ście połączymy z „późnogotyckim romanizmem”) oraz bliższe mu czasowo elewacje wewnętrzne świątyni w mazowieckim Kozłowie Szlacheckim.

${ }^{63}$ Analogiczne formy elewacji bocznych spotykamy np. w weneckim kościele Madonna dell'Orto.

${ }^{64}$ Por. np. L. Kajzer, Wieże zamków Prowincji wielkopolskiej, „Archeologia Historica Polonia" 2002, XII, tu: s. 47-48.
} 
zuje bliski czas powstania tych kościołów i bliski stosunek ich fundatorów przedstawicieli wyższego kleru. Kościół w Raciążku oraz fara krotoszyńska zdecydowanie wyróżniają się przy tym skalą na tle ówczesnej architektury wielkopolskiej.

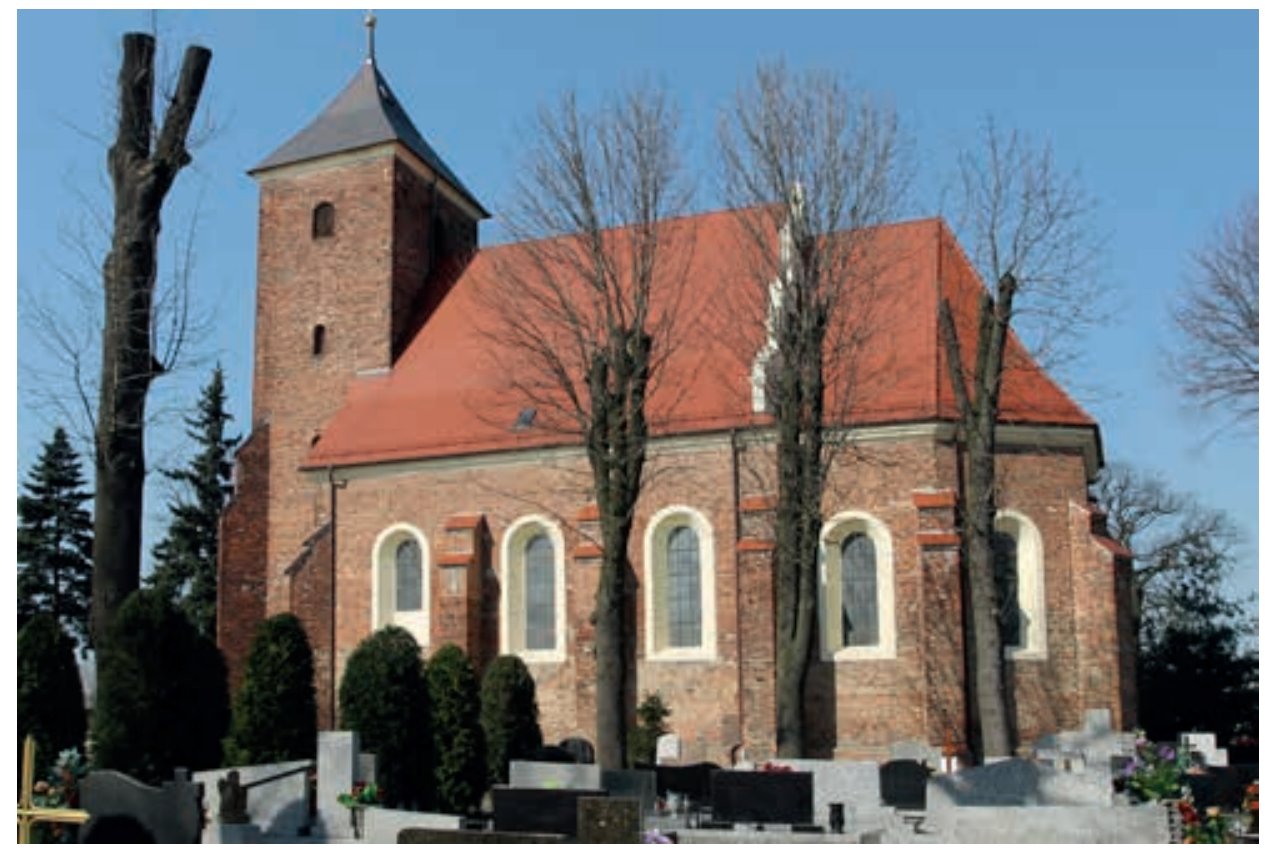

9. Kościół parafialny w Benicach, widok od południa, XVI/XVII w., fot. W. Miedziak

Jako grupa świątynie Rozdrażewskich stanowią niemal wzorcową reprezentację, swoistą sumę wszystkich cech architektury regionu na przełomie XVI i XVII wieku. W kościołach wielkopolskich pojawiają się te same rozwiązania przestrzenne - mam tu na myśli zarówno kościoły jednonawowe (np. w Lubotyniu, Grodzisku Tureckim, Czerniejewie), jak i krzyżowe, trzynawowe (np. w Borku Wielkopolskim). Przy gotycko-nowożytnej formie zewnętrznej murów stosuje się nowożytną sztukaterię (np. w Czarnkowie), szczyty przetwarzają tradycje gotyckie (Rajsko, Rychwał), wprowadzają formy manierystyczno-renesansowe (Mielżyn, Owińska - kościół cysterek) bądź też łączą te tendencje (np. kościół św. Wojciecha w Poznaniu). 


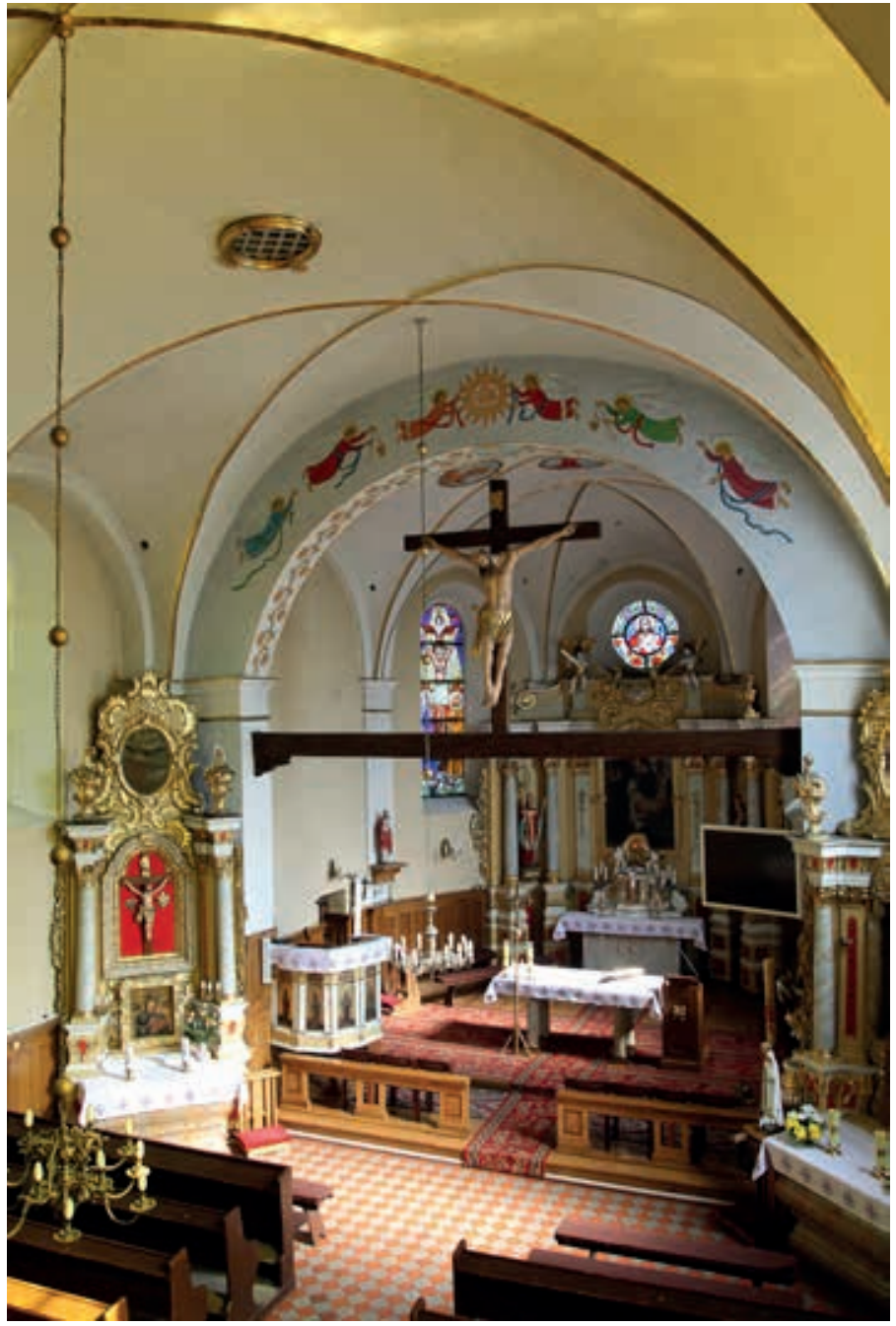

10. Kościół parafialny w Benicach, widok z chóru muzycznego ku wschodowi, XVI/XVII w., fot. W. Miedziak

\section{ZAKOŃCZENIE}

Określenie „gotyk nowożytny” dotyczy zjawiska istotnego w europejskiej architekturze sakralnej, obejmującego zasięgiem całą środkowo-wschodnią część kontynentu ${ }^{65}$. W granicach Rzeczypospolitej architektura tego typu nie wykształciła tak spektakularnych form jak np. w Czechach czy na terenie

65 Zob. np. Krasny, „Jestem katolikiem...”, passim. 
Rzeszy. Mimo to nie można powiedzieć, by była nieistotna - panorama architektoniczna szeroko rozumianej Wielkopolski od drugiej tercji XVI wieku do pierwszych dziesięcioleci wieku XVII była bowiem konsekwentnie i jednolicie "gotycko-nowożytna" ( $z$ różnym natężeniem pierwiastków gotyckiego i nowożytnego).

Analiza fundacji sakralnych rodziny Rozdrażewskich z przełomu XVI i XVII wieku pokazuje, że wielkopolskie świątynie tego czasu nie są świadectwem architektonicznej stagnacji, ale dowodem na powolny rozwój budownictwa gotyckiego. Formy, z których korzystano, nie mogły być uważane za przeszłe, skoro należały do teraźniejszości i odpowiadały, choć skromnie, na pojawiające się wówczas zmiany w sztuce. Rozwój architektury opierał się przede wszystkim na kompilacji gotyckich wzorów $z$ architekturą nowożytną, choć nie stroniono ani od rozwijania form gotyckich, ani od korzystania $z$ form renesansowych, na co wskazują detale, jak np. szczyty, sklepienia etc., oraz mała architektura, tj. kaplice. Wśród typów architektonicznych przeważają modele ukształtowane w gotyku (bazylikowy i jednonawowy z wieżą, zamknięte trójbocznie czy jednonawowy zamknięty prostą ścianą). Jednak co do motywów architektonicznych mamy też formy, które kojarzą się zarówno z gotykiem (ostrołuk, skarpy, sklepienia żebrowe, szczyty schodkowe), późnogotyckim „neoromanizmem” (lizeny, fryz arkadkowy), jak i repertuarem wspólnym architekturze nowożytnej i późnogotyckiej (wewnętrzne filary przyścienne). Elementy gotyckie bywają poddawane częściowej „modernizacji" (sklepienia krzyżowe na drutach jak w Benicach lub z wąskimi żebrami o zwornikach w formie nowożytnych plakiet jak w Rozdrażewie, gotycki szczyt schodkowy z płycinami przetworzony i „unowocześniony” przez formę nowożytnych frontoników w Raciążku). Zarazem mamy też do czynienia z kreatywnym przetwarzaniem form gotyckich, przede wszystkim w Pieniążkowie i Grabienicach.

Osobnych rozważań wymaga pytanie, na ile gotycko-nowożytne formy ówczesnej architektury były kwestią wyboru zleceniodawców i architektów, na ile zaś nieuświadamianym stadium rozwoju północnoeuropejskiej architektury, będącym wypadkową zderzenia silnej tradycji gotyckiej z wpływami nowożytności. Otwarty też pozostaje problem celowej lub niecelowej archaizacji. Wobec ukazanej panoramy budowli, których fundatorami byli zarówno protestanci, jak i katolicy, trzeba powiedzieć, że jej formalna spoistość nie wydaje się odzwierciedlać konfesyjnych podziałów. Dalsze badania przyniosą zapewne kolejne pytania i odpowiedzi. 


\section{BIBLIOGRAFIA}

Adamski J., Uwaga na temat datowania kaplic przy farze w Nowym Mieście nad Warta, w: Sztuka w Wielkopolsce, red. M. Błaszczyński, B. Górecka, M. Górecki, A. Paradowska, Poznań 2013, s. 22-31

Archiwum Archidiecezjalne w Poznaniu, Acta Visitationum 53, 1790

Chrzanowski T., „Neogotyk około 1600” - próba interpretacji, w: Sztuka około roku 1600. Materiały Sesji SHS, Lublin, listopad 1972, Warszawa 1974, s. 75-112

Chrzanowski T., Czyżby spuścizna po katedrze płockiej?, w: Nobile claret opus. Studia z dziejów sztuki dedykowane Mieczysławowi Zlatowi, red. L. Kalinowski et al., Wrocław 1998, s. 243-252

Czyżewski K.J., M. Walczak, O średniowiecznych wzorach nowożytnych kościołów z kaplicami „in modum crucis” na ziemiach Rzeczypospolitej, w: Sztuka dawnej ziemi chełmińskiej i województwa bełskiego, red. P. Krasny, Kraków 1999, s. 25-49

Dobrowolski T., Sztuka polska, Kraków 1974

Dworzaczkowa J., Bracia czescy w Wielkopolsce w XVI i XVII wieku, Warszawa 1997

Dworzaczkowa J., Kowalska H., [hasło:] Rozdrażewski (Rozrażewski) Jan h. Doliwa, w: Polski Słownik Biograficzny, 1989-1991, 31, s. 371-373

Gmiterek H., Bracia czescy a kalwini w Rzeczypospolitej. Połowa XVI - połowa XVII wieku. Studium porównawcze, Lublin 1987

Gryglewski P., De sacra antiquitate. Odwołania do przeszłości w polskiej architekturze sakralnej XVI wieku, Warszawa 2012

Gryglewski P., Oddziaływanie nowożytnej katedry płockiej na przemiany w polskiej architekturze sakralnej w XVI w. - uwag kilka, w: Sztuka Polski środkowej - studia, t. V, red. K. Stefański, P. Gryglewski, Łódź 2011, s. 27-47

Grzybkowski A., Gotycka architektura murowana w Polsce, Warszawa 2014

Günther H., Die ersten Schritte in die Neuzeit. Gedanken zum Beginn der Renaissance nördlich der Alpen, w: Wege zur Renaissance. Beobachtungen zu den Anfängen neuzeitlicher Kunstauffasung im Rheinland und in den Nachbargebieten um 1500, red. N. Nussbaum, Köln 2003, s. 30-87

Harasimowicz J., Treści i funkcje ideowe sztuki śląskiej reformacji. 1520-1650, Wrocław 1986

Harasimowicz J., Fundacje sakralne różnowierczej szlachty polskiej w XVI i XVII wie$\mathrm{ku}$, w: Fundacje i fundatorzy w średniowieczu i w epoce nowożytnej, red. E. Opaliński, T. Wiśnicz, Warszawa 2000, s. 142-153

Hipp H., Studien zur „Nachgotik” des 16. und 17. Jahrhunderts in Deutschland, Böhmen, Österreich und der Schweiz, Tübingen 1979

Jakimowicz T., Sztuka renesansu i manieryzmu. Architektura, w: Dzieje Wielkopolski, t. 1, red. J. Topolski, Poznań 1969

Jurkowlaniec G., Epoka nowożytna wobec średniowiecza. Pamiątki przeszłości, cudowne wizerunki, dzieła sztuki, Wrocław 2008

Kajzer L., Wieże zamków Prowincji wielkopolskiej, w: Archeologia Historica Polonia, t. 12, Toruń 2002, s. 4771

Kohte J., Verzeichnis der Kunstdenkmäler der Provinz Posen, t. 3, Berlin 1898 
Konieczka-Śliwińska D., Dzieje Margonina w dobie staropolskiej, w: Dzieje Margonina, red. K. Rzepa, Poznań 2002, s. 27-51

Kossowski A., Protestantyzm w Lublinie i na Lubelszczyźnie w XVI-XVII w., Lublin 1933

Kowalska H., [hasło:] Rozdrażewski (Rozrażewski) Hieronim h. Doliwa, w: Polski Słownik Biograficzny, 1989-1991, 31, s. 355-365

Kowalski J., Gotyk wielkopolski, Poznań 2010

Kozierowski S., Szematyzm historyczny ustrojów parafialnych dzisiejszej Archidiecezji Poznańskiej, Poznań 1935

Krasny P., Zbór kalwiński w Oksie. Przyczynek do badań nad forma centralnq w polskiej architekturze sakralnej XVI wieku, w: Magistro et Amico amici discipulique. Lechowi Kalinowskiemu w osiemdziesięciolecie urodzin, red. J. Gadomski, Kraków 2002, s. 271-281

Krasny P., „Jestem katolikiem a nie papista”. Świadomość konfesyjna fundatorów a problem prowincjonalizmu architektury sakralnej w Europie środkowej około roku 1600, w: Centrum, prowincje, peryferia. Wzajemne relacje w dziejach sztuki, red. P. Gryglewski, K. Stefański, R. Wróbel, Łódź 2013, s. 69-91

Krotoski K., Dzieje miasta Krotoszyna. Część pierwsza: Miasto Krotoszyn i jego dziedzice za czasów polskich (od 1415 do 1779), Krotoszyn 1930

Kubiček A., Betlemská kaple, Praha 1953

Kujawski W., [hasło:] Rozdrażewski (Rozrażewski) Nowomiejski Jan h. Doliwa, w: Polski Słownik Biograficzny, 1989-1991, 31, s. 373-374

Kurzej M., Kościół parafialny pw. św. Małgorzaty Antiocheńskiej w Zborowie na Szaryszu. Przyczynek do dyskusji nad zjawiskiem postgotyku w Europie Środkowej, „Modus. Prace z Historii Sztuki” 2005, 5, s. 5-22

Kurzej M., Jan Wolff. Monografia architekta $w$ świetle analizy prefabrykowanych elementów dekoracji sztukatorskich, Kraków 2009

KZP III, Województwo kieleckie:

7. Powiat opatowski, red. J.Z. Łoziński, B. Wolff, 1959

KZSP XI, Województwo bydgoskie:

1. Powiat aleksandrowski, oprac. J. Frycz, T. Chrzanowski i M. Kornecki, 1969

3. Bydgoszcz i okolice (d. pow. bydgoski), oprac. T. Chrzanowski i M. Kornecki oraz T. Juraszowie, 1977

15. Powiat świecki, oprac. T. Chrzanowski i T. Żurkowska, 1970

Łukaszewicz J., Krótki opis historyczny kościołów parochialnych, kościółków, kaplic, klasztorów, szkółek parochialnych, szpitali i innych zakładów dobroczynnych w dawnej dyecezyi poznańskiej, t. 2, Poznań 1859

Miłobędzki A., Architektura polska XVII wieku, Warszawa 1980

Mittelalterliche Architektur in Polen. Romanische und gotische Baukunst zwischen Oder und Weichsel, t. 2, red. C. Herrmann, D. von Winterfeld, Petersberg 2015

Panofsky E., Das erste Blatt aus dem "Libro” Giorgio Vasaris. Eine Studie über die Beurteilung der Gotik in der italienischen Renaissance (mit einem Exkurs über zwei Fassadenprojekte Domenico Beccafumis), „Städel-Jahrbuch” 1930, 6, s. 26-72

Rousteau-Chambon H., Le gothique des Temps modernes. Architecture religieuse en milieu urbain, Paris 2003 
Samek J., Nawrót do gotyku w sztuce Krakowa 1 poł. XVII wieku, „Foliae Historiae Atrium" 1968, 5, s. 71-130

Schmidt M., Reverentia und Magnificentia. Historizität in der Architektur Süddeutschlands, Österreichs und Böhmens vom 14. bis 17. Jahrhundert, Regensburg 1999

Schock-Werner B., Die Bauten im Fürstbistum Würzburg unter Julius Echter von Mespelbrunn. Struktur, Organisation, Finanzierung und künstlerische Bewertung, Regensburg 2005

Sokołowski M., G. Worobjew, J.S. Zubrzycki, Kościoły i cmentarze warowne w Polsce, „Sprawozdanie Komisji Historii Sztuki” 1905, 7, s. 481-528

Zaucha T., Tradycja gotycka w architekturze sakralnej ziem ruskich Korony, Kraków 2015

Witold Miedziak

Instytut Historii Sztuki

Uniwersytet im. Adama Mickiewicza w Poznaniu

\section{CHURCHES FOUNDED BY THE ROZDRAŻEWSKI FAMILY - PROBLEMS OF STYLE AND THE MEANING OF FORM}

\section{Summary}

The paper is a monograph of the churches founded by the Doliwita Rozdrażewski family, which make a significant percent of the total number of churches built in the region of Wielkopolska at the turn of the $17^{\text {th }}$ century. Those churches, constructed under the supervision of Hieronim, Archbishop of Włocławek, and the Poznań Chamberlain Jan, have not been analyzed by scholars, and some of them have not been even mentioned in scholarly publications. The analysis presented in the paper allows one to consider the churches founded by the Rozdrażewski family in the context of the architecture of the region, Poland, and the neighboring countries. The features of the period, as well as a religious controversy among the family members, made it possible to approach a number of problems connected to contemporary artistic changes, such as the so-called "gothic style around 1600," relations between Protestant and Roman Catholic architecture, and claims about the purposeful "archaism" of the architecture of the period, emulating the Romanesque or the Gothic style. Responding to the research postulates formulated by other scholars, the author proposed a new term, "early modern Gothic," coined to replace other, ambiguous terms referring to the architecture of those times. Moreover, he proposed an innovative way of interpreting Gothic architecture of the early modern period, based on following its transformations from the end of the Middle Ages till the turn of the $17^{\text {th }}$ century, which results in a claim that Gothic architecture continued until then.

Keywords:

the Rozdrażewski family, post-Gothic style, early modern architecture, Wielkopolska, church foundations 
